\title{
Impact of Cancer Treatment on Cognitive Function: A Systematic Review of Data in Hematological Malignancies
}

\author{
Shruthi Kodad ${ }^{1}$, Mohammed Elemary ${ }^{1}$, Julie Stakiw ${ }^{1}$, Mark Bosch ${ }^{1}$, Hadi Goubran ${ }^{1}$, Ibraheem \\ Othman $^{2}$ and Waleed Sabry*1 \\ ${ }^{1}$ Hematology, Saskatoon Cancer Centre, Saskatoon, Canada
}

${ }^{2}$ Hematology, Allan Blair Cancer Centre, Regina, Canada

*Corresponding author: Waleed Sabry, Blood and Marrow Transplant Program, Saskatoon Cancer Center, Saskatoon, SK. S7N $4 \mathrm{H} 4$, Canada

ARTICLE INFO $\quad$ ABSTRACT

Received: 幽 February 26, 2020

Published: 慧 March 09, 2020

Citation: Shruthi K, Mohammed E, Julie S, Mark B, Waleed S, et al., Impact of Cancer Treatment on Cognitive Function: A Systematic Review of Data in Hematological Malignancies. Biomed J Sci \& Tech Res 26(3)2020. BJSTR. MS.ID.004349.
Cognitive function refers to the activities of the brain necessary to generate complex behaviors for day to day tasks. A significant proportion of patients with cancers including hematologic malignancies might present with some degree of baseline cognitive dysfunction prior to treatment. With clinical advances and emerging treatment strategies, we are currently more able to treat older adult population. Consequently, we are encountering various side effects including long-term neurocognitive sequelae. Cognitive dysfunction may present as impaired concentration, impaired memory or difficulty in carrying out multiple tasks independent of disease status. Cognitive sequelae not only affect the quality of life but also pose an additional challenge in disease management. Studies have also demonstrated an association between chemotherapy and neurodegeneration leading to acceleration of the age-related cognitive decline. The purpose of this article is to review the impact of chemotherapy along with radiotherapy and stem cell transplant on cognitive functions. Most studies focus on effects of radiotherapy on childhood acute lymphoblastic leukemia (ALL) and Primary Central Nervous System (CNS) lymphoma. In this review, we have made an attempt to identify the risk factors, manifestations, possible hypotheses for the impaired cognition in Acute Leukemia, Myelodysplastic syndromes, Lymphomas, Multiple Myeloma and stem cell transplant recipients. Possible interventional strategies to prevent and reverse cognitive decline are also discussed.

\section{Introduction}

In the last decade, new treatment strategies, innovative drugs, targeted therapies and stem cell transplants in hematological malignancies have increased the overall survival in patients. With the availability of disease-specific and safer therapeutic modalities, the age group of treatment-eligible patients is expanding. Impaired cognition has been known to be a disease manifestation in various cancers [1]. Chemotherapy-associated cognitive dysfunction, otherwise known as 'chemobrain', is a well-recognized entity. The term 'chemobrain' is more often used for a subjective experience of cognitive deficits during or after the chemotherapy [2]. 'Cognitive impairment or cognitive dysfunction' is used to identify objectively measurable deficiencies in cognition using the recommended tests which measure memory, learning, executive functions, processing speed etc. [2]. The subjective cognitive deficits and objective impairment is not always concordant, but this might simply be the nature of the 'chemobrain' rather than being a measurement artefact [2].

The association between cranial radiation and cognitive impairment has been well established. Radiation-induced inflammation affecting the hippocampal microenvironment and 
white matter integrity causing dysregulated neurogenesis to have been described in various studies [3,4]. Chemotherapy and cranial radiotherapy are known to cause neurocognitive deficiencies leading to impaired attention, learning, memory, and speed of processing information [5]. These can last for months or years after treatment and range from mild to severe [6]. The purpose of this review is to summarise the effects of chemotherapy with or without radiotherapy and stem cell transplant on various cognitive domains in adults with various hematological malignancies.

\section{Methods}

A systematic search of literature published in Englishlanguage was done using electronic databases - PubMed/ MEDLINE. Literature published between the year 1994 and 2018 was reviewed. The following keywords were used: Cognitive impairment, cognitive dysfunction, quality of life, chemotherapy, cancer, autologous transplant, allogeneic transplant, hematological malignancy, leukemia, and lymphoma. Disease-specific searches were done using the words cognitive dysfunction and cognitive impairment. Studies on the pediatric population and articles on solid tumors were excluded. Studies evaluating neurocognitive outcomes in adults treated for childhood cancers have been included. Article types considered for review were randomized controlled trials, observational studies, prospective studies, journal article, multicentre studies, and clinical trials. Case reports were excluded. A total of 13 articles were considered for review based on the inclusion criteria described above.

\section{Cognitive Domains}

Neurocognitive disorder comprises a group of clinical syndromes characterized by loss of previously acquired cognitive functions which affect personal, social and occupational aspects of life [7]. Cognitive domains evaluated for neurocognitive status include attention and concentration, perceptual processing, learning and working memory, abstract thinking and executive function, language, information processing speed, motor functions and emotions [8].

\section{Acute Lymphoblastic Leukemia (ALL)}

The 5-year survival rate of childhood ALL is about 90\% $[9,10]$. Consequently, there are an increasing number of adult survivors with a history of childhood ALL with long-term side effects. There is compelling evidence to suggest an association between cranial radiation for ALL and cognitive decline in adult survivors [11]. A cross-sectional study by Armstrong, et al. [11] evaluated 265 survivors of childhood ALL by using Wechsler Memory Scale IV for four memory domains: immediate, delayed, auditory and visual. Eighty-five of them also underwent a structural and functional assessment by magnetic resonance imaging (MRI). The mean age of subjects was 37.7 years and median time from cranial radiotherapy
(CRT) was 30 years. The number of patients grouped into high dose CRT (24Gy; n-138) and low dose CRT (18Gy; n-127) was not significantly different. Ninety-five percent of them had intrathecal methotrexate (MTX) and 75\% had exposure to intravenous (IV) MTX. Due to evolving treatment strategies over the years, patients who received 24Gy CRT were older than the 18Gy group. However, memory battery scores were age-adjusted for direct comparison. Compared with age-adjusted normal controls, the 24Gy group had significantly increased impairment in immediate and delayed memory and scored very low on Brief Cognitive Status Exam (BCSE) indicating reduced cognitive status. The18Gy group did not reflect these findings suggesting a dose-response effect. Immediate memory impairment was associated with smaller bilateral temporal lobe volumes. Impaired delayed memory was associated with thinner parietal and frontal cortices.

As a result of CRT associated cognitive decline, chemotherapyonly protocols have evolved, and CRT is used for the highest risk patients. Approximately $30 \%$ of children chemotherapy only regimens experience some degree of cognitive decline when compared to healthy controls [12]. Recent studies have suggested that neurocognitive dysfunction after MTX treatment is a result of altered metabolism of chemotherapy due to genetic polymorphisms [13]. A study by Elens, et al. [14] identified cerebrospinal fluid phosphorylated Tau (CSF p-Tau) as a predictor of neurocognitive sequelae. Intellectual performance, memory and executive functions were compared between 31 childhood ALL survivors and 35 healthy controls. Childhood ALL survivors showed significantly lower total, verbal, and performance intelligence quotients than healthy controls (P value .001,.02, and .007, respectively). Elevated levels of p-Tau and higher MTX dose negatively correlated with intellectual performance in ALL survivors [14]. Cheung et al evaluated 226 adult survivors who had received chemotherapy alone in ALL. The adult study population had lower than population norms of focused attention, motor and visual processing speed and executive functions [15].

\section{Acute Myeloid Leukemia (AML) and Myelodysplastic Syndrome (MDS)}

Anemia associated with fatigue and cognitive dysfunction is seen in numerous cancers. Previous studies have reported the association between low hemoglobin and its effect on fatigue and cognitive function. One study reported a smaller subset of patients experiencing poor attention and visual memory when hemoglobin levels dropped below 12g/dL [16]. Another study reported difficulty in concentrating and lower processing speed at a hemoglobin level of less than 8g/dL [17]. A cross-sectional study by Wood, et al. [18] investigated the level of hemoglobin decline causing cognitive dysfunction using cutoff values 12,10 , and $8 \mathrm{~g} /$ dL in 55 AML and MDS patients. This study confirmed the findings of previous research that anemia does affect functional aspects of 
frontotemporal lobe by demonstrating impaired immediate and delayed word retrieval, divided attention and working memory, and fine motor dexterity. However, the effects in moderate and severe anemia groups were more pronounced as compared to the mild anemia group. This study concluded that a hemoglobin level of 10 $\mathrm{g} / \mathrm{dL}$ or below is associated with changes in cognitive functioning. In contrast, Meyers, et al. [1] studied a similar population of AML/MDS (n-54) and did not find a significant association between anemia and cognitive functions. The patients underwent assessments for similar cognitive domains and had serum levels of Interleukin (IL)1, 6, 8 and tumor necrosis factor $-\alpha$ (TNF- $\alpha$ ) measured. Baseline assessments revealed preserved attention span and psychomotor speed in this population. However, $>40 \%$ of patients had difficulty in learning new information and 33\% of patients experienced impaired fine motor coordination. The post-treatment group did not show any effect of chemotherapy on cognitive functions however fatigue did worsen. This might be a skewed result as only $50 \%$ of patients were followed up and the numbers are small $(n=26)$. This study demonstrated a strong co-relation between IL-6 levels and poor executive functions and association of high IL-8 levels with good memory as IL-8 enhances hippocampal cells in vitro [1].

\section{Chronic Myeloid Leukemia (CML)}

Table 1: Demographics and characteristics of studies.

\begin{tabular}{|c|c|c|c|c|c|c|}
\hline Author, Year & Study Design & Disease group & Treatment & $\begin{array}{c}\text { No. of } \\
\text { Patients }\end{array}$ & Age (Yr) & Timing of Tests \\
\hline $\begin{array}{l}\text { Scherwath, et al. } \\
{[31]}\end{array}$ & Prospective & $\begin{array}{c}\text { AML, MDS, MF, MM, } \\
\text { NHL, CLL, CML, } \\
\text { PV, AA }\end{array}$ & Allo HSCT & 102 & 47.7 & $\begin{array}{l}\text { At admission } \\
\text { At } 100 \text { days } \\
\text { At } 1 \text { year }\end{array}$ \\
\hline Elens, et al. [14] & $\begin{array}{c}\text { Retrospective } \\
\text { cross-sectional } \\
\text { study }\end{array}$ & Childhood ALL & NA & 35 & 21.5 & $\begin{array}{l}\text { Compared with } \\
\text { controls } \\
\text { CSF p-Tau and } \\
\text { MTX dose during } \\
\text { treatment } \\
\text { correlation with } \\
\text { Neurocognitive } \\
\text { assessment in } \\
\text { Childhood ALL } \\
\text { survivors }\end{array}$ \\
\hline $\begin{array}{c}\text { Armstrong, et al. } \\
{[11]}\end{array}$ & $\begin{array}{l}\text { Cross-sectional } \\
\text { study }\end{array}$ & $\begin{array}{l}\text { Adult survivors of } \\
\text { childhood ALL }\end{array}$ & Chemotherapy + Radiotherapy & 265 & 36 & $\begin{array}{l}\text { Median time from } \\
\text { CRT: } 30 \text { years }\end{array}$ \\
\hline Jones, et al. [30] & $\begin{array}{l}\text { Cross-sectional } \\
\text { study }\end{array}$ & MM & Auto HSCT & 53 & 58 & $\begin{array}{l}\text { Pre-Auto HSCT } \\
\text { 1-month post } \\
3 \text { months post }\end{array}$ \\
\hline $\begin{array}{l}\text { Kindermann, et al. } \\
\text { [33] }\end{array}$ & Prospective study & $\begin{array}{l}\text { AML, ALL, CML, } \\
\text { MM, } \\
\text { Lymphoma, MF, } \\
\text { CMML, AA }\end{array}$ & Allo HSCT & 39 & 45.6 & $\begin{array}{l}\text { Pre Allo } \\
\text { At } 100 \text { days }\end{array}$ \\
\hline $\begin{array}{l}\text { Ghazikhanian, et } \\
\text { al. [35] }\end{array}$ & Prospective study & $\begin{array}{l}\text { Lymphoma, MM, } \\
\text { AML, MF, CLL, CML }\end{array}$ & Allo + Auto HSCT & 138 & 60.4 & $\begin{array}{l}\text { Pre HSCT } \\
\text { At } 1 \text { year }\end{array}$ \\
\hline Sostak, et al. [34] & Prospective study & $\begin{array}{l}\text { AML, ALL, MDS, } \\
\text { CLL, Lymphoma, } \\
\text { AA }\end{array}$ & Allo HSCT & 71 & $37 \pm 9$ & $\begin{array}{l}2 \pm 4 \text { months before } \\
\text { transplant } \\
14 \pm 3 \text { months post- } \\
\text { transplant }\end{array}$ \\
\hline Scheibel, et al. [23] & Prospective study & CML & $\begin{array}{c}\text { Interferon- } \alpha \pm \text { Hydroxyurea/Low } \\
\text { dose Ara C }\end{array}$ & 30 & 46.5 & $\begin{array}{c}\text { Baseline } \\
\text { On-treatment }\end{array}$ \\
\hline $\begin{array}{l}\text { Meadows, et al. } \\
{[22]}\end{array}$ & $\begin{array}{l}\text { Longitudinal } \\
\text { analysis }\end{array}$ & $\begin{array}{l}\text { CML stable, CML } \\
\text { Accelerated, MDS }\end{array}$ & $\begin{array}{c}\text { Imatinib/Hydroxyurea/Interferon } \\
\pm \text { HSCT }\end{array}$ & 77 & 48.6 & $\begin{array}{l}\text { Baseline } \\
\text { At } 12 \text { months } \\
\text { At } 18 \text { months }\end{array}$ \\
\hline Meyers, et al. [1] & Not reported & AML, MDS & $\begin{array}{l}\text { Lipodaunocin+cytoxan } \\
\pm \text { topotecan/thalidomide }\end{array}$ & & 60.2 & $\begin{array}{c}\text { Baseline } \\
\text { Response at } 1 \\
\text { month }\end{array}$ \\
\hline
\end{tabular}




\begin{tabular}{|c|c|c|c|c|c|c|}
\hline Wood, et al. [18] & $\begin{array}{l}\text { Cross sectional } \\
\text { study }\end{array}$ & AML, MDS & Pre-treatment & 88 & 61 & $\begin{array}{l}\text { Pre-treatment } \\
\text { - Association } \\
\text { of anemia } \\
\text { and cognitive } \\
\text { dysfunction }\end{array}$ \\
\hline Khan, et al. [27] & $\begin{array}{l}\text { Prospective cohort } \\
\text { study }\end{array}$ & NHL & $\begin{array}{c}\text { CHOP } \\
\text { R-CHOP }\end{array}$ & 68 & 43.56 & $\begin{array}{c}\text { Baseline - } \\
\text { Timepoint } 0 \\
\begin{array}{c}\text { day before the } \\
\text { 2nd cycle }\end{array} \\
\begin{array}{c}1 \text { day before the } \\
\text { 3rd cycle }\end{array} \\
\begin{array}{c}1 \text { day before the } \\
\text { 4th cycle }\end{array}\end{array}$ \\
\hline Else, et al. [25] & $\begin{array}{l}\text { Randomised } \\
\text { multicentre trial }\end{array}$ & CLL & $\begin{array}{c}\text { Chlorambucil } \\
\text { Fludarabine } \\
\text { Fludarabine+Cyclophosphamide }\end{array}$ & 777 & 65 & $\begin{array}{c}\text { Baseline } \\
3 \text { months } \\
6 \text { months } \\
12 \text { months } \\
\text { Annually up to } 5 \\
\text { years }\end{array}$ \\
\hline
\end{tabular}

Table 2: Summary of Neurocognitive tests used and outcomes of the studies.

\begin{tabular}{|c|c|c|c|c|c|c|}
\hline Author, Year & Study Design & Disease Group & Treatment & $\begin{array}{c}\text { No. of } \\
\text { Patients }\end{array}$ & Age (Yr) & Timing of Tests \\
\hline $\begin{array}{c}\text { Scherwath, et al. } \\
{[31]}\end{array}$ & Prospective & $\begin{array}{c}\text { AML, MDS, MF, MM, } \\
\text { NHL, CLL, CML, } \\
\text { PV, AA }\end{array}$ & Allo HSCT & 102 & 47.7 & $\begin{array}{l}\text { At admission } \\
\text { At } 100 \text { days } \\
\text { At } 1 \text { year }\end{array}$ \\
\hline Elens, et al. [14] & $\begin{array}{c}\text { Retrospective } \\
\text { cross-sectional } \\
\text { study }\end{array}$ & Childhood ALL & NA & 35 & 21.5 & $\begin{array}{l}\text { Compared with } \\
\text { controls } \\
\text { CSF p-Tau and } \\
\text { MTX dose during } \\
\text { treatment } \\
\text { correlation with } \\
\text { Neurocognitive } \\
\text { assessment in } \\
\text { Childhood ALL } \\
\text { survivors }\end{array}$ \\
\hline $\begin{array}{c}\text { Armstrong, et al. } \\
{[11]}\end{array}$ & $\begin{array}{l}\text { Cross-sectional } \\
\text { study }\end{array}$ & $\begin{array}{l}\text { Adult survivors of } \\
\text { childhood ALL }\end{array}$ & Chemotherapy +Radiotherapy & 265 & 36 & $\begin{array}{l}\text { Median time from } \\
\text { CRT: } 30 \text { years }\end{array}$ \\
\hline Jones, et al. [30] & $\begin{array}{l}\text { Cross-sectional } \\
\text { study }\end{array}$ & MM & Auto HSCT & 53 & 58 & $\begin{array}{l}\text { Pre-Auto HSCT } \\
\text { 1-month post } \\
3 \text { months post }\end{array}$ \\
\hline $\begin{array}{c}\text { Kindermann, et al. } \\
{[33]}\end{array}$ & Prospective study & $\begin{array}{l}\text { AML, ALL, CML, } \\
\text { MM, } \\
\text { Lymphoma, MF, } \\
\text { CMML, AA }\end{array}$ & Allo HSCT & 39 & 45.6 & $\begin{array}{l}\text { Pre Allo } \\
\text { At } 100 \text { days }\end{array}$ \\
\hline $\begin{array}{l}\text { Ghazikhanian, et } \\
\text { al. [35] }\end{array}$ & Prospective study & $\begin{array}{l}\text { Lymphoma, MM, } \\
\text { AML, MF, CLL, CML }\end{array}$ & Allo + Auto HSCT & 138 & 60.4 & $\begin{array}{l}\text { Pre HSCT } \\
\text { At } 1 \text { year }\end{array}$ \\
\hline Sostak, et al. [34] & Prospective study & $\begin{array}{l}\text { AML, ALL, MDS, } \\
\text { CLL, Lymphoma, } \\
\text { AA }\end{array}$ & Allo HSCT & 71 & $37 \pm 9$ & $\begin{array}{c}2 \pm 4 \text { months before } \\
\text { transplant } \\
14 \pm 3 \text { months post } \\
\text { transplant }\end{array}$ \\
\hline Scheibel, et al. [23] & Prospective study & CML & $\begin{array}{c}\text { Interferon- } \alpha \pm \text { Hydroxyurea/Low } \\
\text { dose Ara C }\end{array}$ & 30 & 46.5 & $\begin{array}{c}\text { Baseline } \\
\text { On-treatment }\end{array}$ \\
\hline
\end{tabular}




\begin{tabular}{|c|c|c|c|c|c|c|}
\hline $\begin{array}{l}\text { Meadows, et al. } \\
{[22]}\end{array}$ & $\begin{array}{l}\text { Longitudinal } \\
\text { analysis }\end{array}$ & $\begin{array}{l}\text { CML stable, CML } \\
\text { Accelerated, MDS }\end{array}$ & $\begin{array}{c}\text { Imatinib/Hydroxyurea/Interferon } \\
\pm \text { HSCT }\end{array}$ & 77 & 48.6 & $\begin{array}{l}\text { Baseline } \\
\text { At } 12 \text { months } \\
\text { At } 18 \text { months }\end{array}$ \\
\hline Meyers, et al. [1] & Not reported & AML, MDS & $\begin{array}{l}\text { Lipodaunocin+cytoxan } \\
\pm \text { topotecan/thalidomide }\end{array}$ & & 60.2 & $\begin{array}{l}\text { Baseline } \\
\text { Response at } 1 \\
\text { month }\end{array}$ \\
\hline Wood, et al. [18] & $\begin{array}{l}\text { Cross sectional } \\
\text { study }\end{array}$ & AML, MDS & Pre-treatment & 88 & 61 & $\begin{array}{l}\text { Pre-treatment } \\
\text { - Association } \\
\text { of anemia } \\
\text { and cognitive } \\
\text { dysfunction }\end{array}$ \\
\hline Khan, et al. [27] & $\begin{array}{l}\text { Prospective cohort } \\
\text { study }\end{array}$ & NHL & $\begin{array}{c}\text { CHOP } \\
\text { R-CHOP }\end{array}$ & 68 & 43.56 & $\begin{array}{c}\text { Baseline - } \\
\text { Timepoint } 0 \\
1 \text { day before the } \\
\text { 2nd cycle } \\
\begin{array}{c}1 \text { day before the } \\
\text { 3rd cycle }\end{array} \\
\begin{array}{c}1 \text { day before the } \\
\text { 4th cycle }\end{array}\end{array}$ \\
\hline Else, et al. [25] & $\begin{array}{l}\text { Randomised } \\
\text { multicentre trial }\end{array}$ & CLL & $\begin{array}{c}\text { Chlorambucil } \\
\text { Fludarabine } \\
\text { Fludarabine+Cyclophosphamide }\end{array}$ & 777 & 65 & $\begin{array}{c}\text { Baseline } \\
3 \text { months } \\
6 \text { months } \\
12 \text { months } \\
\begin{array}{c}\text { Annually up to } 5 \\
\text { years }\end{array}\end{array}$ \\
\hline
\end{tabular}

Tyrosine Kinase Inhibitors (TKIs) are the mainstay of CML treatment. Pulmonary, cardiovascular and gastrointestinal side effects secondary to TKIs are very well documented in the literature [19]. TKIs impacting quality of life by causing fatigue and depression have also been well documented in previous studies [20,21]. A longitudinal study by Meadows, et al. [22] conducted cognitive assessments on 77 patients. CML constituted $86 \%$ of the study population. Treatment for CML patients included a combination of Imatinib, Hydroxyurea, Interferon or stem cell transplant. Cognitive domains described in Tables 1 \& 2 were assessed at baseline, at 12 months and at 18 months post treatment intervals. Mild cognitive impairment was noticed at baseline, but no effect of baseline anemia was observed on cognitive functions. Eighty percent of the patients were reported impaired at baseline and at 18 months this number had decreased to $64 \%$. While most other studies used educational achievement, performance in school or employment as a measure for cognitive reserve, this study utilized Intelligence Quotient (IQ) for the same. It was demonstrated that individuals with higher IQ improved on most of the domains at 18-month mark except for executive function. Majority of the patients were stable CML and the sample size was too small to derive conclusions about post-transplant chronic graft versus host disease (cGVHD) causing adverse effects on cognition.

Interferon- $\alpha$ (IFN- $\alpha$ ) was used for transplant ineligible CML patients in the past. Now with the advent of TKIs, its use is much less. Schiebel, et al. [23] reported a prospective study involving 30 CML patients treated with IFN- $\alpha(n-13)$, IFN- $\alpha$ and low dose cytosine arabinoside (n-15) and IFN- $\alpha$ and hydroxyurea(n-2). A standardized neuropsychological battery of test was administered (Table 2) at baseline and when treatment assessments were carried on. Sixteen patients (53.3\%) experienced cognitive decline of 1.5 standard deviations (SD) on one or more of the cognitive tests. IFN- $\alpha$ with chemotherapy group showed significant performance decline in word learning task i.e. Consistent Long-Term Retrieval (CLTR) and Controlled Oral Word Association Test (COWAT) during treatment. This study discussed the possibility of increased neurotoxicity due to a higher dose and duration of IFN- $\alpha$ along with chemotherapy. Patients on IFN- $\alpha$ develop neurotoxicity and present with mild symptoms of frontal and subcortical brain deficits [24]. Schiebel, et al. [23] showed similar findings with IFN $-\alpha$ causing deficiency in information processing and frontal lobe executive functions. This study also confirmed that depression is one of the side effects of IFN- $\alpha$, however, correlation between depression and cognitive measures were not significant [23].

\section{Chronic Lymphocytic Leukemia (CLL) and Lymphomas}

CLL is the most common leukemia affecting patients $>65$ years of age. A multicentre prospective trial, by Else, et al. [25], randomized patients to receive Chlorambucil, Fludarabine alone or with Cyclophosphamide (FC). Health related quality of life (HRQoL) 
was assessed at 8 time points as described in Table 1. Cognitive functioning was one of the 15 domains assessed in HRQoL. At 3 months, self-reported cognitive dysfunction was noticed in 19\% of patients who received Chlorambucil and 38\% of patients who received FC. These seem to be an underestimate as data from nonresponders were more likely to be missing. At the end of 5 years $43 \%$ of patients were dead leading to under representation of older population or patients with more aggressive disease at later time points. Holzner, et al. [26] compared 76 CLL patients with 152 healthy controls. The CLL group reported a lower quality of life in all domains. This was more pronounced in female patients. Although these studies are informative, both are dependent on a subjective assessment. Objective assessments are needed to determine the cognitive domains affected [26].

There is well documented evidence that inflammatory cytokine release secondary to chemotherapy can cause cognitive impairment. Addition of Rituximab to CHOP has improved cure rates in NonHodgkin's Lymphoma (NHL). Khan, et al. [27] enrolled 68 patients of NHL and divided them equally into CHOP receiving and R-CHOP receiving groups. In both groups increase in pro inflammatory cytokines and low thyroid hormone levels were observed. In the R-CHOP group, elevated levels of IL-6, IL-1 $\beta$ and decreased levels of T3, T4 with more cognitive decline (determined by Mini-Mental State Examination) was observed compared to CHOP group. Krull, et al. [28] analysed neurocognitive and brain imaging outcomes in 62 adult survivors of childhood Hodgkin's Lymphoma (HL) who were 15 years post treatment. They had received anthracycline based chemotherapy along with higher ( $\geq 30 \mathrm{~Gy}$ ) or lower $(<30 \mathrm{~Gy})$ dose of thoracic radiation. Forty-five percent of survivors were found to be impaired on tests of memory, $43 \%$ on tests of processing speed and $27 \%$ on tests of attention and $25 \%$ on executive function without any significance of radiation dose [28]. Anthracyclines have been implicated in cognitive decline when used to treat other malignancies [29]. Krull, et al. [28] hypothesized that thoracic radiation induced cardiovascular side effects leads to central nervous system morbidities leading to cognitive decline.

\section{Hematopoietic Stem Cell Transplant (HSCT)}

Autologous HSCT prolongs disease free survival and allogeneic HSCT is a curative treatment option in most hematological malignancies. Both modalities are associated with complex acute and chronic complications. Recently, there is an increased insight into neurocognitive side effects of HSCT. Jones et al reported acute cognitive impairment in Multiple Myeloma (MM) patients, pre and post autologous transplant. A total of $53 \mathrm{MM}$ patients was recruited. Pre autologous HSCT, $47 \%$ of patients (25/53) showed cognitive impairment based on the overall cognitive functional index (OCFI). More frequent deficits were observed in learning, memory, and executive functions. One month post Autologous HSCT, 20/41 patients (48.8\%) showed clinically significant decline on 1 or more measures which was based on practice effect adjusted reliable change index (RCI-PE) from their post induction performance. Eight of 41 patients showed decline in 3 or more measures. These declines were mainly observed in learning/memory and motorfunction domains. At the 3-month post autologous HSCT follow up, 48\% (14/29) showed clinically significant decline on 1 or more measures. In this cohort, $25 \%$ of patients showed stable or improving performance on all cognitive domains throughout the study. Jones et al also identified that post induction deficits and higher number of induction chemotherapy cycles were strong predictors for subsequent cognitive decline [30].

The eligible age group for allogeneic HSCT is widened. Transplant is now being offered for patients who are older than 65 years of age. A recent survey showed that gathering information about neurocognitive dysfunction was the topmost concern in patients and second most important concern in caregivers [8]. All those patients may have some amount of baseline cognitive dysfunction due to previous chemo-radiotherapy. In a multicenter study, Scherwath, et al. followed 102 allogeneic HSCT recipients. Forty-seven percent had baseline cognitive impairment in $\geq 1 / 5$ domains (T0) i.e. one domain was affected in 34\% and 2 domains in $13 \%$ of patients. After one year of transplant (T2), $41 \%$ showed neurocognitive dysfunction in at least one of the domains, however, range of impaired domains increased affecting one domain in 31\%, 2 domains in $8 \%$ and 3 domains in $2 \%$ of the patients. Interestingly, $16 \%$ of the $41 \%$ patients did not have any baseline impairment [31]. Bevans, et al. [32] demonstrated that difficulty to concentrate was one of the commonest symptoms reported by 3-year survivors [32].

Kindermann, et al. [33] assessed 39 patients before admission (T0) and 19 of these were reassessed 100 days after HSCT(T1). Eleven $(28.2 \%)$ of 39 patients had received extended therapies before HSCT. HRQoL assessment showed significant decline in physical functioning $(\mathrm{P}=0.001)$ from baseline to $\mathrm{T} 1$. One domain at T0 and 2 at T1, both related to memory and were below population norms. Executive functions were better than population norms at both time points. Except for significant decline in simple reaction time ( $\mathrm{p}=0.01)$, no other parameters differed between T0 and T1. The results of this study was in contrast to other studies showing high prevalence of cognitive sequelae post-transplant [34]. One reason might be because in the post-transplant group, 12/19 patients received reduced intensity conditioning and only 1 received TBI. However, numbers are too small to interpret whether higher dose leads to a greater cognitive impairment. Ghazikhanian, et al. [35] demonstrated that HSCT patients experience more sleep problems than general population and these patients also experienced more cognitive issues [35]. A prospective follow up of 71 allogeneic bone marrow transplant patients, $14 \pm 3$ months posttransplant, by Sostak, et al. [34] reported neurologic sequelae in $65 \%$ of patients. Acute neurologic complications of defined origin were seen in 13/71 patients and were excluded from analysis. 
New neurologic signs predominantly affecting peripheral nervous system were found in $47 \%$ of patients. Neurocognitive impairment was found in $51 \%$ of patients after HSCT which was less than baseline impaired population (58\%). Short disease duration, female sex, disease duration $<20$ months were found to be the factors influencing improvement. The cognitive improvement after HSCT was attributed to reduced emotional distress compared to pre-transplant period. A practice effect also could not be excluded in this study [34].

Post-transplant cognitive status assessment is difficult as there might be no baseline scores available to compare with. The cognitive status also depends on patients 'educational and IQ level. Syrjala, et al. [36] assessed neurocognitive function in 92 survivors and demonstrated that most of them recovered to pretransplant level. The same study also demonstrated $41.5 \%$ of patients to have some residual cognitive impairment [37]. These can seriously affect patients' QoL, activities of daily living, difficulty in medication management leading to missed doses and errors. There are many risk factors causing post-transplant cognitive impairment. Conditioning chemotherapy using Fludarabine based regimens and total body irradiation (TBI-12Gy) and even reduced intensity conditioning may all lead to increased neurotoxicity [20]. Immunosuppressive drugs used for GVHD prophylaxis like calcineurin inhibitors (Cyclosporine and Tacrolimus) increase the risk of cognitive impairment as these drugs cause neurotoxic side effects like posterior reversible encephalopathy syndrome (PRES) and thrombotic microangiopathy (TMA) [38]. Infections like Cytomegalovirus (CMV) and Epstein - Barr virus (EBV) can affect non-verbal memory, attention span and speed of cognitive performance [39].

\section{Suggestions and Conclusion}

Risk factors for neurocognitive dysfunction in hematological malignancies include high intensity cancer treatment, cranial radiation, female gender, co-existing neurologic problems, sleep deprivation, depression, fatigue, absence of social partner, HSCT, extensive chronic GVHD, use of corticosteroids, narcotics, and sedatives [35,40-43]. Evaluation and documentation of neurocognitive deficits using standard neuropsychological battery of tests at baseline, during treatment, pre and post HSCT will help us gain more insight into the problem. This will allow us to recognize at-risk population and help us choose an optimal chemotherapy/conditioning regimen. For example, avoidance of total body/cranial irradiation or substitution of Busulfan for a TBI based conditioning regimen $[44,45]$. In patients with pre-existing seizure disorder, avoiding medications lowering seizure threshold will be useful. Careful assessment of need of narcotics, steroids and sedatives must be undertaken. Early recognition of CNS infections, PRES, TMA and optimum management of these will help mitigate some cognitive issues.
Cognitive rehabilitation measures for childhood leukemia survivors, school re-entry programs, psychosocial support, employment assistance, using an integrated approach to manage diet, sleep disorders and anxiety may also be beneficial [4648]. To conclude, neurocognitive dysfunction in hematological malignancies can be a cause of serious morbidity. There is a need for validation and development of screening tests for neurocognitive dysfunction. Awareness about risk factors is needed to undertake timely interventions and to counsel patients about neurocognitive sequelae. Appropriate rehabilitation measures should be made available which will not only improve quality of life but also aid in achieving better overall outcomes.

\section{References}

1. Meyers CA, Albitar M, Estey E (2005) Cognitive impairment, fatigue, and cytokine levels in patients with acute myelogenous leukemia or myelodysplastic syndrome. Cancer 104(4): 788-793.

2. Wang X, Walitt B, Saligan L, Cheung CW, Zhang Z, et al. (2016) HHS Public Access 72(1): 86-96.

3. Makale MT, Mc Donald CR, Hattangadi Gluth JA, Kesari S (2016) Mechanisms of radiotherapy-associated cognitive disability in patients with brain tumours. Nat Rev Neurol 13(1): 52-64.

4. Paulino AC,SimonJH,Zhen W,Wen BC (2000) Long-term effects in children treated with radiotherapy for head and neck rhabdomyosarcoma. Int J Radiat Oncol Biol Phys 48(5):1489-1495.

5. J Dietrich, M Monje, J Wefel, C Meyers (2008) Clinical Patterns and Biological Correlates of Cognitive Dysfunction. Associated with Cancer Therapy, Oncologist.

6. S Africa (2017) HHS Public Access 4(11): 835-846.

7. JG Scott, B Ostermeyer, AA Shah (2016) Neuropsychological Assessment in Neurocognitive Disorders. Psychiatr Ann 46(2): 118-126.

8. D Buchbinder, DL Kelly, RF Duarte, JJ Auletta, N Bhatt, et al. (2018) Neurocognitive dysfunction in hematopoietic cell transplant recipients: Expert review from the late effects and Quality of Life Working Committee of the CIBMTR and complications and Quality of Life Working Party of the EBMT. Bone Marrow Transplant 53(5): 535-555.

9. AB Mariotto, JH Rowland, KR Yabroff, S Scoppa, M Hachey, et al. (2009) Long-Term Survivors of Childhood Cancers in the United States. Cancer Epidemiol Biomarkers Prev 18(4): 1033-1040.

10. SP Hunger, ML Loh, WL Carroll, M Devidas, EA Raetz (2013) Childrens Oncology Groups 2013 Bueprint for Research: Acute Lymphoblastic Leukemia. Pediatr Blood Cancer 60(6): 957-963.

11. GT Armstrong, WE Reddick, RC Petersen, A Santucci, N Zhang, et al (2013) Evaluation of memory impairment in aging adult survivors of childhood acute lymphoblastic leukemia treated with cranial radiotherapy. J Natl Cancer Inst 105(12): 899-907.

12. PC Nathan, K Wasilewski Masker, LA Janzen (2009) Long-term Outcomes in Survivors of Childhood Acute Lymphoblastic Leukemia. Hematol Oncol Clin North Am 23(5): 1065-1082.

13. KR Krull, P Brouwers, N Jain, L Zhang, L Bomgaars, et al. (2008) Folate Pathway Genetic Polymorphisms are Related to Attention Disorders in Childhood Leukemia Survivors. J Pediatr.

14. I Elens, S Deprez, M Danckaerts, P Bijttebier, V Labarque, et al. (2017) Neurocognitive Sequelae in Adult Childhood Leukemia Survivors Related to Levels of Phosphorylated Tau. JNCI J Natl Cancer Inst 109(7): 5-8.

15. YT Cheung, KR Krull (2016) HHS Public Access 901: 108-120. 
16. J PB, GLL, M Booth Jones, D KA, T CL, et al. (2004) Relationship of hemoglobin levels to fatigue and cognitive functioning among cancer patients receiving chemotherapy. J Pain Symptom Manag.

17. WS Brown, JT Marsh, D Wolcott, R Takushi, CR Carr, et al. (1991) Cognitive function, mood and P3 latency: Effects of the amelioration of anemia in dialysis patients. Neuropsychologia.

18. SM Wood, CA Meyers, S Faderl, HM Kantarjian, SA Pierce, et al. (2011) Association of anemia and cognitive dysfunction in patients with acute myelogenous leukemia and myelodysplastic syndrome. Am J Hematol 86(11): 950-952.

19. L Caldemeyer, M Dugan, J Edwards, L Akard (2016) Long-Term Side Effects of Tyrosine Kinase Inhibitors in Chronic Myeloid Leukemia. Current Hematologic Malignancy Reports.

20. KM Phillips, J Pinilla Ibarz, E Sotomayor, MR Lee, HSL Jim, et al. (2013) Quality of life outcomes in patients with chronic myeloid leukemia treated with tyrosine kinase inhibitors: A controlled comparison. Support Care Cancer.

21. L Kalmanti, S Saussele, M Lauseker, MC Müller, CT Dietz, et al. (2015) Safety and efficacy of imatinib in CML over a period of 10 years: data from the randomized. CML-study IV, Leukemia 29(5): 1123-1132.

22. ME Meadows, G Chang, JA Jones, JR Antin, EJ Orav (2013) Predictors of Neuropsychological Change in Patients with Chronic Myelogenous Leukemia and Myelodysplastic Syndrome. Arch Clin Neuropsychol 28(4): 363-374.

23. RS Scheibel, AD Valentine, S OBrien, CA Meyers (2004) Cognitive Dysfunction and Depression During Treatment with Interferon-Alpha and Chemotherapy. J Neuropsychiatry Clin Neurosci 16(2): 185-191.

24. AR Sas, H Bimonte Nelson, CT Smothers, J Woodward, WR Tyor (2009) Interferon- Causes Neuronal Dysfunction in Encephalitis. J Neurosci.

25. M Else, K Cocks, S Crofts, R Wade, SM Richards, et al. (2012) Quality of life in chronic lymphocytic leukemia: 5-Year results from the multicenter randomized LRF CLL4 trial. Leuk Lymphoma 53(7): 1289-1298.

26. Holzner B, Kemmler G, Kopp M, Nguyen Van Tam D, Sperner Unterweger B, et al. (2004) Quality of life of patients with chronic lymphocytic leukemia: results of a longitudinal investigation over 1 year. Eur J Haematol 72(6): 381-389.

27. MA Khan, K Garg, D Bhurani, NB Agarwal (2016) Early manifestation of mild cognitive impairment in B-cell non-Hodgkins lymphoma patients receiving CHOP and rituximab-CHOP chemotherapy. Naunyn Schmiedebergs Arch Pharmacol 389(12): 1253-1265.

28. KR Krull, ND Sabin, WE Reddick, L Zhu, G Armstrong, et al. (2012) Neurocognitive function and CNS integrity in adult survivors of childhood Hodgkin lymphoma. J Clin Oncol.

29. SR Kesler, DW Blayney (2016) Neurotoxic effects of anthracycline- vs nonanthracycline-based chemotherapy on cognition in breast cancer survivors. JAMA Oncol 2(2): 185-192.

30. D Jones, EG Vichaya, XS Wang, MH Sailors, CS Cleeland, et al. (2013) Acute cognitive impairment in patients with multiple myeloma undergoing autologous hematopoietic stem cell transplant. Cancer 119(23): 41884195 .

31. A Scherwath, L Schirmer, M Kruse, G Ernst, M Eder, et al. (2013) Cognitive functioning in allogeneic hematopoietic stem cell transplantation recipients and its medical correlates: A prospective multicenter study. Psychooncology 22(7): 1509-1516.

32. MF Bevans, SA Mitchell, JA Barrett, MR Bishop, R Childs, et al. (2014) Symptom distress predicts long-term health and well-being in allogeneic stem cell transplantation survivors. Biol Blood Marrow Transplant.
33. F Schulz Kindermann, A Mehnert, A Scherwath, L Schimer, B Schleimer, et al. (2007) Cognitive function in the acute course of allogeneic hematopoietic stem cell transplantation for hematological malignancies. Bone Marrow Transplant 39(12): 789-799.

34. P Sostak, CS Padovan, TA Yousry, G Ledderose, HJ Kolb, et al. (2003) Prospective evaluation of neurological complications after allogeneic bone marrow transplantation. Neurology 60(5): 842-848.

35. SE Ghazikhanian, CS Dorfman, TJ Somers, MLO sullivan, HM Fisher, et al. (2017) Cognitive Problems Following Hematopoietic Stem Cell Transplant: Relationships with Sleep, Depression, and Fatigue. Bone Marrow Transplant 52(2): 279-284.

36. KL Syrjala, SB Artherholt, BF Kurland, SL Langer, S Roth Roemer, et al. (2011) Prospective neurocognitive function over 5 years after allogeneic hematopoietic cell transplantation for cancer survivors compared with matched controls at 5 years. J Clin Oncol 29(17): 2397-2404.

37. KL Syrjala, SB Artherholt, BF Kurland, SL Langer, S Roth Roemer, et al. (2011) Prospective neurocognitive function over 5 years after allogeneic hematopoietic cell transplantation for cancer survivors compared with matched controls at 5 years. J Clin Oncol 29(17): 2397-2404.

38. S Phipps, SN Rai, WH Leung, S Lensing, M Dunavant (2008) Cognitive and academic consequences of stem-cell transplantation in children. J Clin Oncol 26(12): 2027-2033.

39. CM Bollard, HE Heslop (2016) T cells for viral infections after allogeneic hematopoietic stem cell transplant. Blood 127(26): 3331-3340.

40. HSL Jim, B Small, S Hartman, J Franzen, S Millay, et al. (2012) Clinical predictors of cognitive function in adults treated with hematopoietic cell transplantation. Cancer 118(13): 3407-3416.

41. AMJ Braamse, JC Yi, OJ Visser, MW Heymans, B van Meijel, et al. (2016) Developing a Risk Prediction Model for Long-Term Physical and Psychological Functioning after Hematopoietic Cell Transplantation. Biol Blood Marrow Transplant 22(3): 549-556.

42. LA Menefee, ED Frank, C Crerand, S Jalali, J Park, et al. (2004) The effects of transdermal fentanyl on driving, cognitive performance, and balance in patients with chronic nonmalignant pain conditions. Pain Med 5(1): 42-49.

43. J Lim, DF Dinges (2010) A Meta-Analysis of the Impact of Short-Term Sleep Deprivation on Cognitive Variables. Psychol Bull 136(3): 375-389.

44. AC Smedler, J Winiarski (2008) Neuropsychological outcome in very young hematopoietic SCT recipients in relation to pretransplant conditioning. Bone Marrow Transplant 42: 515-522.

45. JH Kramer, MR Crittenden, FE Halberg, WM Wara, MJ Cowan (1992) A prospective study of cognitive functioning following low-dose cranial radiation for bone marrow transplantation. Pediatrics 90(3): 447-450.

46. AE Hammerstrom, J Howell, A Gulbis, G Rondon, RE Champlin, et al. (2013) Tacrolimus-associated posterior reversible encephalopathy syndrome in hematopoietic allogeneic stem cell transplantation. Am J Hematol 88(4): 301-315

47.E Gavriilaki, I Sakellari, A Anagnostopoulos, RA Brodsky (2017) Transplant-associated thrombotic microangiopathy: Opening Pandoras Box. Bone Marrow Transplanrt 52(10): 1355-1360.

48. Castellino SM, Ullrich NJ, Whelen MJ, BJ Lange (2014) Developing interventions for cancer-related cognitive dysfunction in childhood cancer survivors. J Natl Cancer Inst 106(8): 1-16. 
ISSN: 2574-1241

DOI: $10.26717 / B J S T R .2020 .26 .004349$

Waleed Sabry. Biomed J Sci \& Tech Res

(c) (P) This work is licensed under Creative

Submission Link: https://biomedres.us/submit-manuscript.php

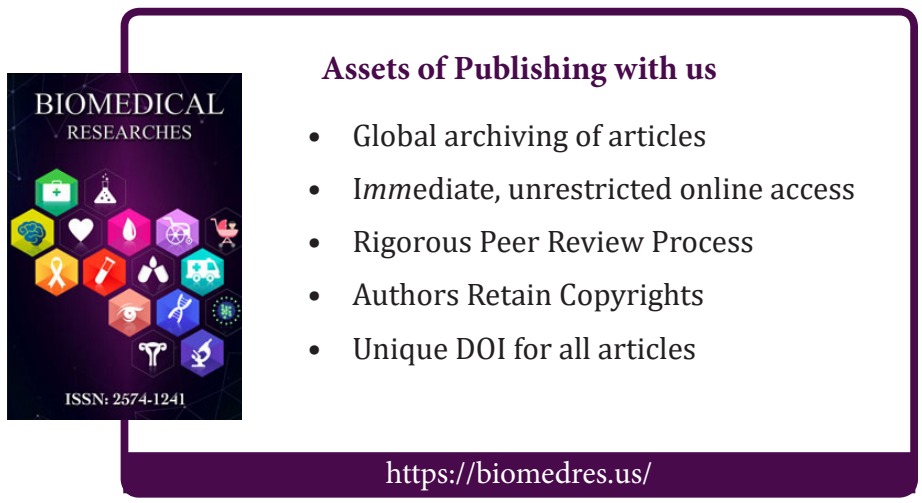

